\title{
Rainfall Variation: Implication on Cocoa Yield in Ondo State, Nigeria
}

\author{
DADA Emmanuel \\ Department of Geography and Planning Sciences \\ Adekunle Ajasin University \\ Akungba-Akoko \\ Ondo State, Nigeria. \\ Email: vissitemma@gmail.com
}

Received: November 7, 2018

Accepted: November 11, 2018

Online Published: November 17, 2018

\begin{abstract}
Cocoa is known as one of the notable cultivated cash crops of the tropical rainforest of the world that is rain dependent. The study examines the effect of rainfall variation on the yield of cocoa plantation in Ondo State, Nigeria. Data used for the study includes the rainfall data of 15 years from 2000 to 2014 collected from Ondo state agro climatological office as well as cocoa yield data for the same period of time from Ondo State ministry of agriculture and forest resources. Descriptive statistical method was employed to determine the relationship between both variables in which the result shows direct relationship between rainfall and cocoa yield. Results were presented using bar charts and line graph for the time series analysis of the variables. Linear regression statistical analysis was used to predict cocoa yield with certain amount of rainfall with the correlation coefficient ' $r$ ' value of 0.97 which implies that rainfall changes go a long way to determine the same variation trend in the cocoa yield. Though, not only the quantity of rainfall within the range of rainfall required for the growth of this crop affect the yield but its distribution. A little millimeter of rainfall above or below the required range of rain for cocoa plantation greatly affects cocoa yield.
\end{abstract}

Keywords: cocoa yield, rainfall variation, relationship, Ondo State.

\section{Introduction}

Cocoa (Theobroma Cacao) is among the most important perennial crops in the world. It is a tropical lowland crop. Cocoa was a dominant foreign exchange earner in Nigeria from the early 1960s through the 1970s (Olujide and Adeogun, 2006). Historically, cocoa contributed average agricultural earning of $70.6 \%$ between 1971 and 1973 , $89.8 \%$ between 1976 and 1980, 84.6\% between 1985 and 1987, 76.8\% between 1986 and 1990, and 53.3\% between 1992 and 1996 respectively. This declining trend observed can be attributed to strong domination of Nigeria export earnings by crude oil and lots of other factors (Agboola, 2005).

It became an important export crop in Southwestern Nigeria and other African countries including Ghana, Ivory Coast, Togo, etc. and attains its peak between 1954 and 1969. During these periods, cocoa became the second 
largest and major source of foreign earner for Nigeria government. This crop provides job for large number of Nigerians and also source of raw material for beverages and chocolate industries (Hokona, 1994; Oyedele, 2007).

According to Adegeye (2006), cocoa was first cultivated in the western region of Nigeria in 1890. It became prominence rapidly in Nigeria to the extent that Nigeria became the world cocoa second largest producer in 1965 (Adegeye, 1996). Cocoa is produced in the tropical rainforests of Ondo, Osun, Ogun, Oyo, Ekiti, Edo, Delta, CrossRivers, Akwa-Ibom and Anambra states with the Ondo state as the largest cocoa producing state in Nigeria (Agegeye, 2006). Cocoa is grown in fourteen out of thirty-six states of Nigeria but mainly produced in the above stated states. It is well known that cocoa production is highly sensitive to changes in climate, from length and intensity of sunshine to rainfall and water application, soil condition and temperature due to evapotranspiration effect (Anim-kwapon \& Frimpong, 2005).

Climatic variation especially rainfall dynamics is one of the serious environmental challenges facing world agricultural productivity especially the perennial crops. The variation can be attributed to natural climatic cycle and majorly, human activities which adversely affect productivity especially in Africa as a result of poor technology (Ziervogel et al., 2006). Evidence from several researches revealed that climatic variation is a global issue, likewise its impacts but most adverse effects were majorly felt in the developing economies, especially those in Africa and Asia, due to low level of their coping capacities (Nwanfor, 2007; Jagtap, 2007). As the planet warms, rainfall pattern deviates and result in extreme events such as drought, floods, forest fire etc. (Zoellick, 2009), this however causes poor and unpredictable yields, thereby making farmers more vulnerable, particularly in Africa (UNFCCC, 2007). Larger proportion of African inhabitants are poor farmers and will mostly bear the brunt of crop failures, reduced agricultural productivity, hunger increase, malnutrition and prevalent of diseases (Zoellick, 2009). Findings by Jones and Thornton (2003) shows that crop yield in Africa may fall by $10-20 \%$ by 2050 or even up to $50 \%$ due to climate change especially rainfall particularly in Africa that is predominantly practice rain-fed agriculture and hence fundamentally dependent on the vagaries of weather.

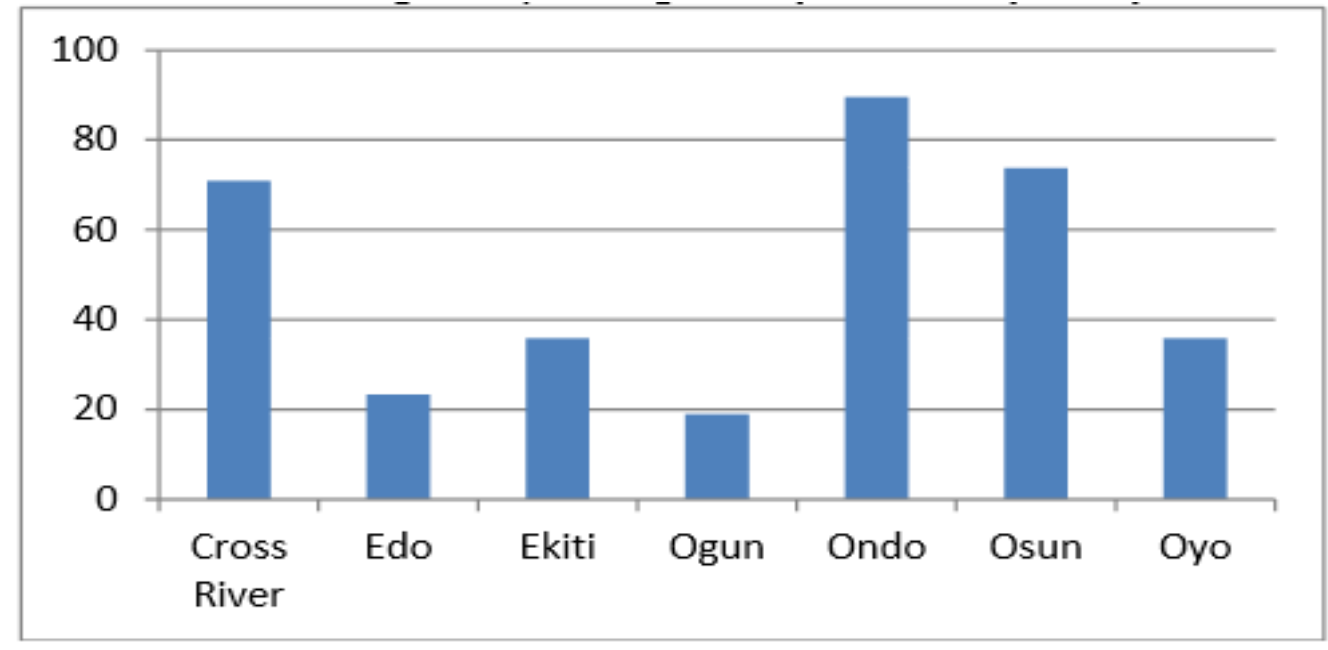

Figure 1: Main Cocoa Producing States in Nigeria between 2006-2010 productions (000mt) (source: National Bureau of Statistics)

As recorded by Food and Agriculture Organization of the United Nations (FAOSTAT 2012), Nigeria is the fourth leading exporter of cocoa in the world with Cote d'Ivoire as the first following by Indonesia and Ghana. Cocoa is the main agricultural export in Nigeria because it accounts for substantial quantity of the country total annual agricultural export contribution to the Gross Domestic (GDP) Export of Nigeria. However, production can be 
increased if government make and implement decisive policy or measures that will enhance production and enlist Nigeria as the first or second cocoa producing and exporting country in the world.

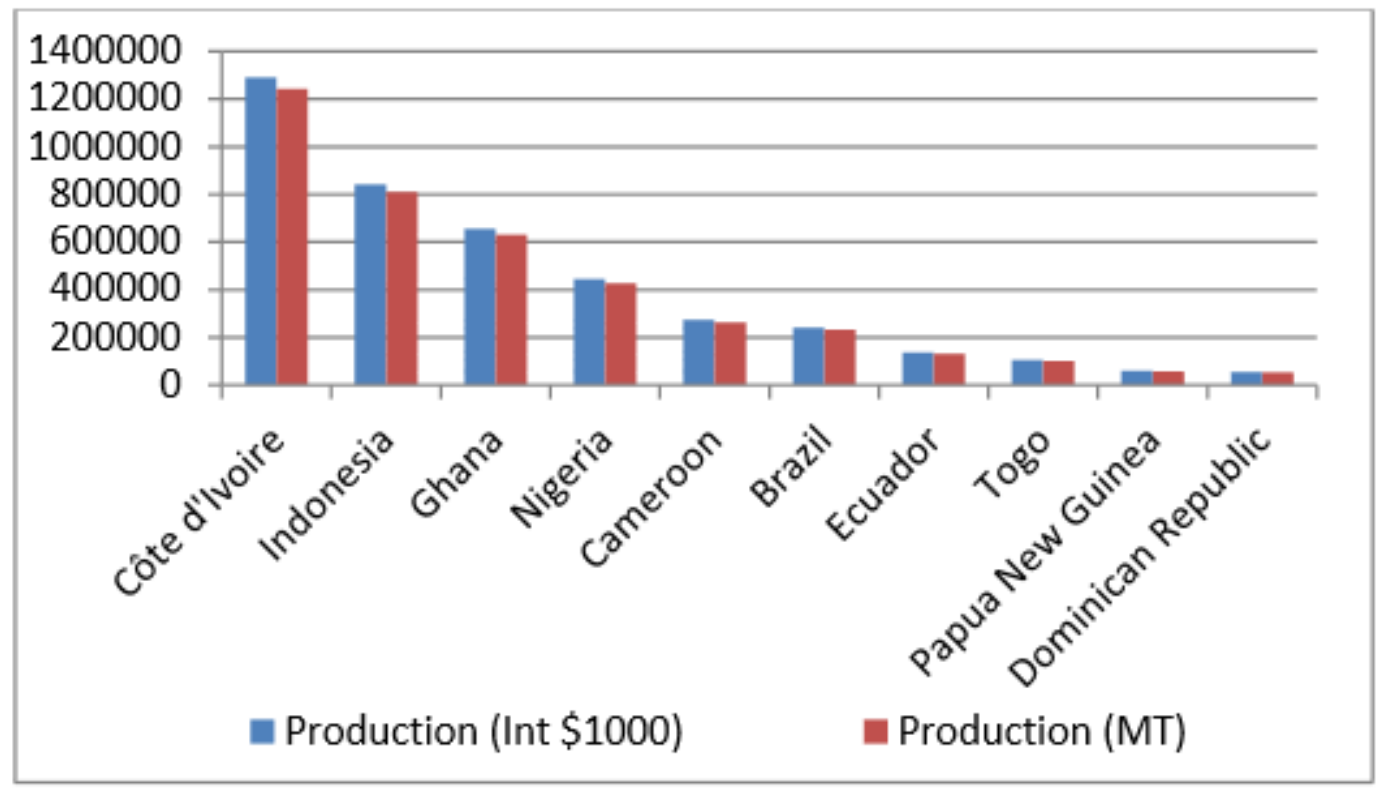

Figure 2: World top ten cocoa producing countries in 2010 (source: FAOSTAT)

\subsection{Climate Change and Cocoa Production}

It is well established that cocoa is highly sensitive to climatic variation from hour of sun, to rainfall and application of water, soil conditions and temperature due to effects on evapo-transpiration. Variation in climate could alter stages and rate of development of cocoa pests and pathogens, modify host resistance and result in changes in the physiology of host-pathogen/pests interaction. The most likely consequences depend on geographical distribution of host of pathogen, affect crop yields and crop loses which will impact socio-economic variables including farm income, livelihood and farm-level decision making. Hence, the need for an understanding of climatic variation impacts on cocoa production and the potential for adaptation to variation of climatic elements are essential.

\section{Material and Methods}

\subsection{The Study Area}

The study area is cocoa plantation in Ondo State Nigeria. It lies within the central cocoa cultivation and forest belt of Southwestern Nigeria, which comprises of Ondo, Osun and Ekiti States. Ondo State is located in the geographical coordinates of $7^{0} 10^{1} \mathrm{~N}$ and $5^{0} 5^{1} \mathrm{E}$. It has the total land area of $15,500 \mathrm{~km}^{2}(6,000 \mathrm{sqm})()$. And it share boundary with Ekiti, Kogi, Edo, Ogun and Osun states.

\subsubsection{Climate}

The climate of Ondo state ranges from tropical wet- and- dry climate with mean annual rainfall of about $1500 \mathrm{~mm}$ and $2000 \mathrm{~mm}$ in the derived savanna and humid forest zones respectively (Adefolalu, 1997). The wet season starts in April and ends in October and dry season commences from November to March, though the average annual amount of rainfall mostly increased to $2500 \mathrm{~mm}$ at the Sothern coast and can reduced to about $1220 \mathrm{~mm}$ in some years at the northern limit of the forest belt (Gilbert, 1969). The mean annual temperature is about $26.6^{0 \mathrm{c}}$ with the average yearly 
humidity of $76.05 \%$. The climate is monsoonal with a contrast between well-defined dry and wet seasons (Adebekun, 1978).

\subsubsection{Geology and Soil}

Ondo state comprises of two distinct geological regions of sedimentary rocks in the Southern part and second is the pre-Cambrian Basement Complex rocks in the northern part of the state. The sedimentary rocks contain mainly postCretaceous sediments and also the Abeokuta Formation of the Cretaceous. The basement complex rocks on the other hand contain the medium grained gneisses which are strongly foliated rocks occurring as an outcrops with alternating bands of dark and light minerals. The light bands color is rich in minerals such as feldspar and quartz and the dark colored bands are full of abundant biotic mica. A portion of the state in the northeast overlies the coarse grained granites and gneisses (A.J. Smyth, 1962). The soil ranges from medium -grained granitic rocks, mediumgrained gneisses and schist which support the development of low rainforest suitable for tree crops such as cocoa, kola, and oil-palm (Ekanade, 2007). The relief of Ondo state is dominated by the plain that rises gently from the coast northwards to the area of crystalline rock where icebergs rise above the surrounding plains (Adebekun, 1978).

\subsubsection{Relief and Drainage}

The state composed of lowlands in the southern part and certain part in the central. And rugged hills with granitic outcrops dominate several places mostly in the northern part of the state. There is a rising of the land from the coastal area in the south i.e. less than 15 meters above sea level to the rugged hills of the north eastern area of Akoko region. The notable hills in Ondo state are found at Idanre and Akoko areas of the state which rise beyond 250 meters above the sea level (Adebekun, 1978). The geomorphological units of the creek and riverine portions of the state contain sand ridges, lagoons, swamp flats, creeks and distributaries of the western Niger Delta (Online Nigeria Community Portal, 2013)/ www.onlinenigeria.com. The major rivers found in Ondo state include: Owena, Oluwa, Oni, Ogbese and Ose and their drainage system characterize with basement complex rocks.

\subsubsection{Vegetation}

The southern and central parts of the state contains natural vegetation of high forest rich in various hardwood for timber such as Melicia excels, Antaris Africana, Iroko, Obeche, Wawa, Terminalia superba, Lophira procera etc. But in the northern part are found the woody savanna and grassland such as Blighia sapida and Parkia biglobosa which dominate the Akoko area (Online Nigeria Community Portal, 2013). The swamp flats are the area of fresh water swamp forests dominated the interior and the units of mangrove vegetation near the coast. Worthy of notice in the state vegetation is the prevalence of tree crops plantation such as cocoa, kola, coffee, rubber, oil palms and citrus with cocoa being the most vital tree crops in the state. Ondo state falls within the evergreen tropical rainforest, a transitional zone between the fresh-water swamps along the coast and Guinea Savanna belt in the north (Ekanade, 1990). 

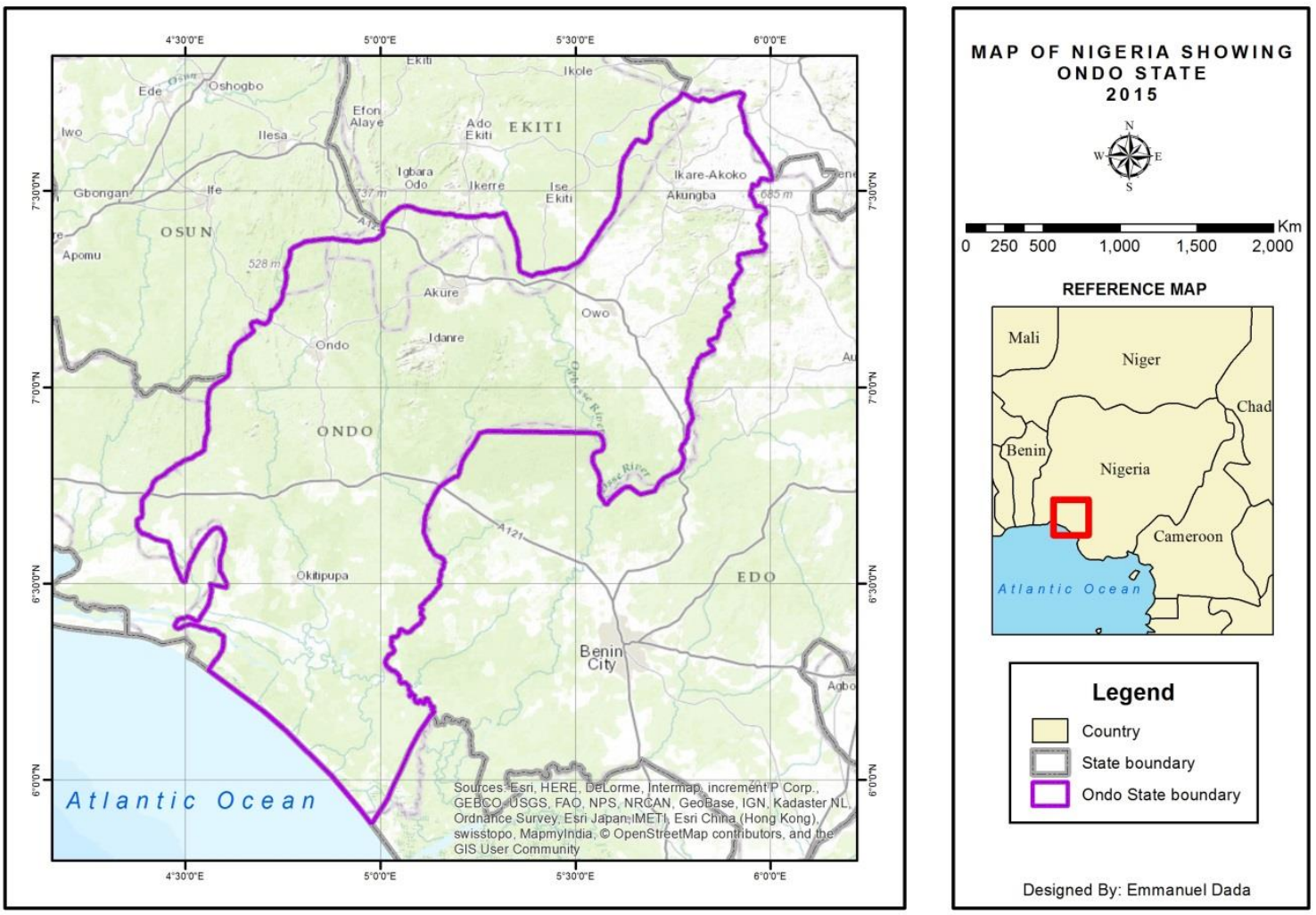

Figure 3: Map of Nigeria showing Ondo State

\subsection{Data Sources}

The study makes use of both primary and secondary data sources. The primary data used in this study was obtained through researcher field survey, focused group discussion and other means of social survey to access information about cocoa farmers perception on how rainfall variation over the years affect their yields and the coping strategies they have adopted over time. The secondary data for this research includes rainfall and cocoa yield data obtained from Agroclimatology department of ministry of Agriculture, Akure, Ondo State.

\subsection{Data Analysis}

The data rainfall and cocoa yield data collected were analysed using both descriptive and inferential statistics. The descriptive statistics involved the used of table and simple percentage while the result were presented with bar charts and line graph to reveal the relationship between mean annual rainfall from year 2000 to 2014 and the yield of cocoa plantation recorded in tons during these same years. Regression inferential statistics was employed to predict the cocoa yield as a result of rainfall variation as the most unstable climate parameter in the study area.

\section{Result and Discussion}

The outcome of the analysis of the rainfall and cocoa yield data are presented and discussed in this section. The results of the descriptive analyses made in the survey were presented with bar charts and line graph to show or reveal how the independent variable (rainfall) determine the performance of dependent variable (cocoa yield). 


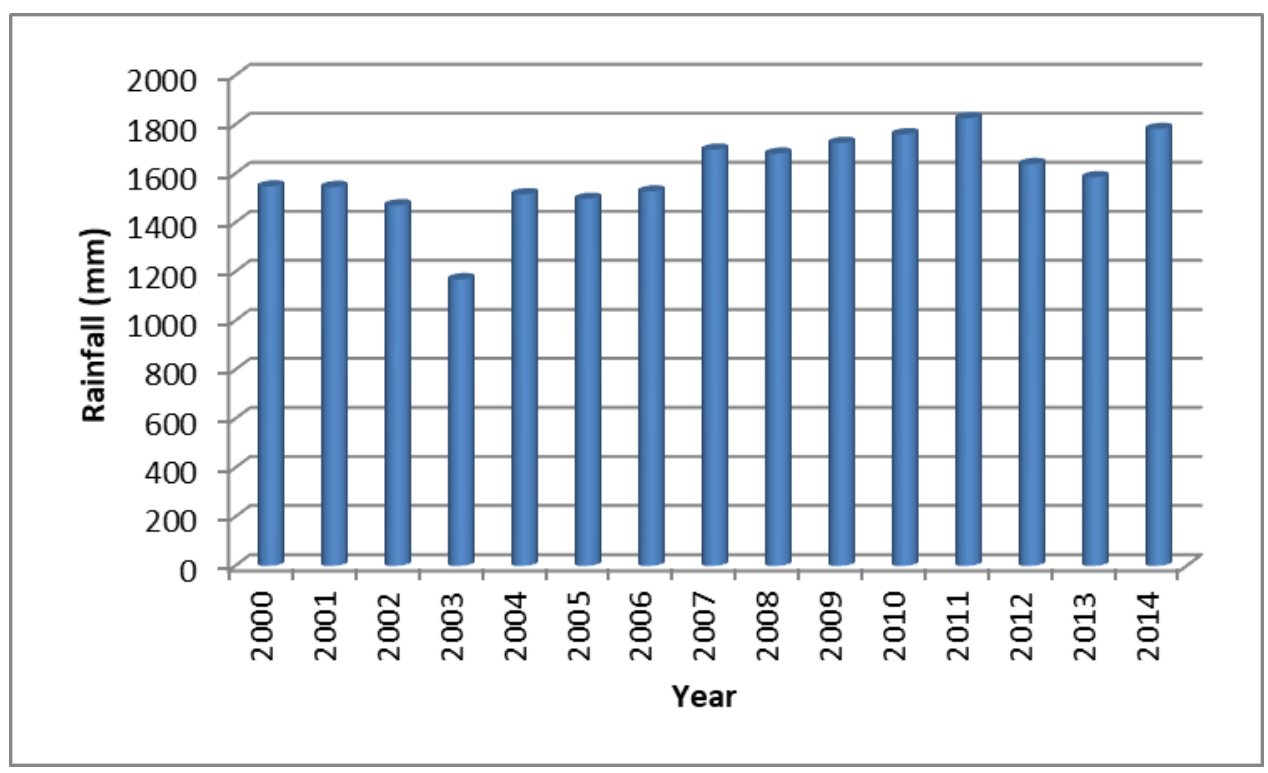

Figure 4: Rainfall distribution between 2000 and 2014

The rainfall bar graph above depicts the distribution of rainfall in the study area between 2000 and 2014 with the highest average annual rainfall of $1826.2 \mathrm{~mm}$ recorded in the year 2011 and lowest mean annual rainfall of 1169.1 $\mathrm{mm}$ recorded in the year 2003. The variation in the mean annual rainfall recorded in the study area can be attributed to climate change which is a global phenomenon. However, the amount of rainfall does not necessarily determine the yield but the distribution of rainfall once the amount of rainfall is up to the minimum amount $(1450 \mathrm{~mm})$ requires for the survival of cocoa plantation.

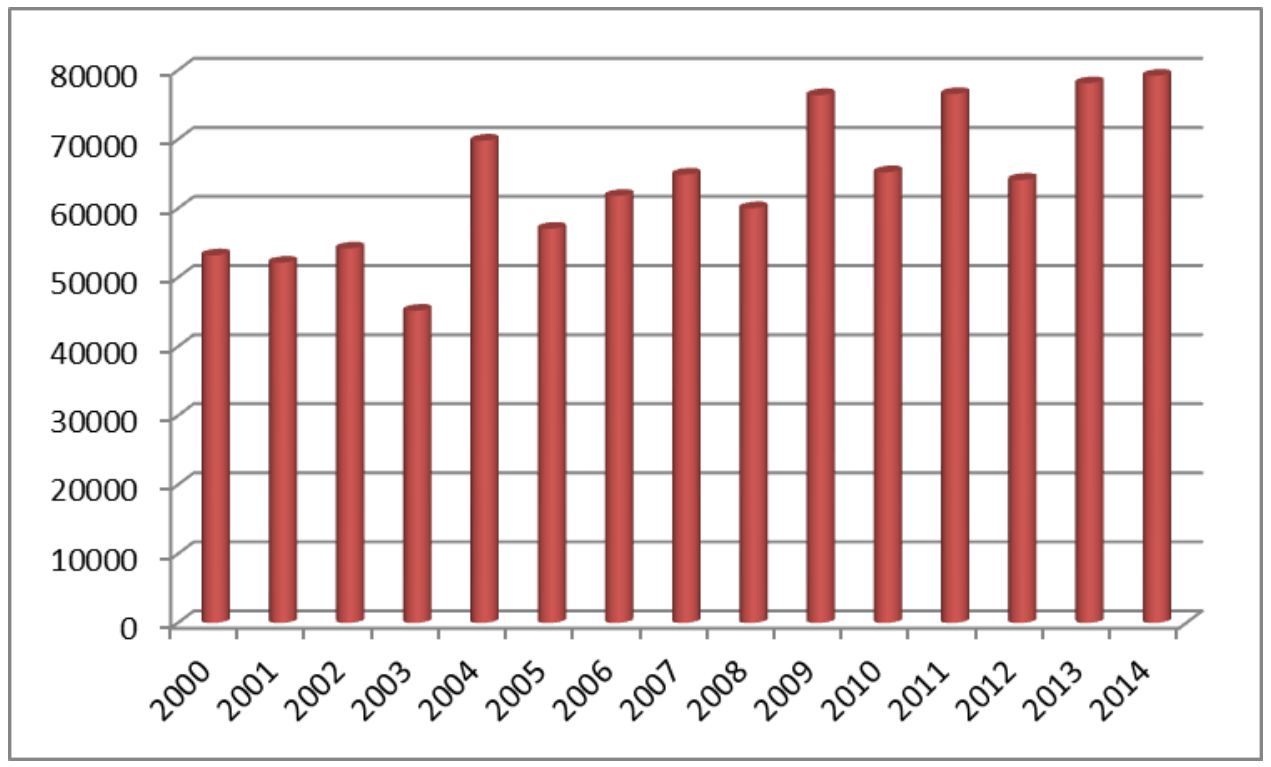

Figure 5: Cocoa yield between 2000 and 2014 
Yield of cocoa plantation is a function of a lot of factors ranging from natural factors such rainfall, temperature, soil etc. to human induced factors such as constant treatment of the plantation with insecticide, pesticide and herbicide to prevent attack from diseases, the application of fertilizer, taken care of the plantation environment against unwanted weed and some other factors. Thus, most of these favorable factors for the better yield of cocoa are available in the study area. Hence, for the purpose of this research, rainfall as a very unstable climatic parameter was considered for the yield of this plantation in the study area. Gradual increase was observed from the cocoa yield graph though not on a regular basis and interval based on various factors some of which was stated above. This gradual increased in the yield justified the result of an increase in the area of land occupied by cocoa plantation in Ondo state as an outcome of the detected change that took place in this plantation during the investigated period of this research. The lowest yield was recorded in the year 2003 with 45203 tons of cocoa and the highest in 2014 with 79210 tons which can be traced to impact of rainfall.

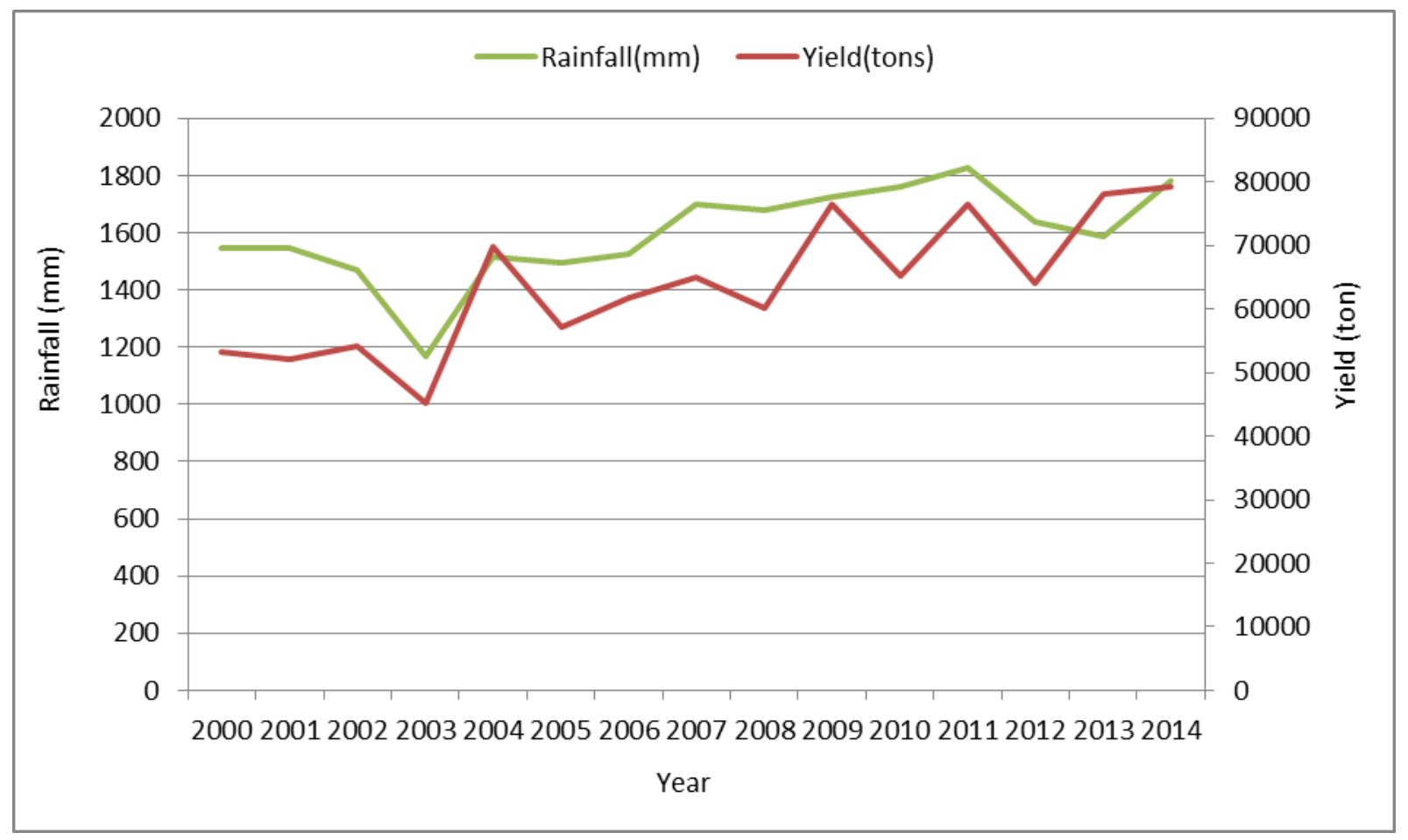

Figure 6: Rainfall and Cocoa yield graph.

The above graph reflects the relationship between rainfall variability and cocoa yields between 2000 and 2014. It can be deducted from the graph that yield is highly dependent on rainfall but not at the same proportion. The highest quantity of cocoa yield was recorded in 2014 with 79210 tons of cocoa and $1782.12 \mathrm{~mm}$ of rainfall during that same year. And the lowest yield was in 2003 with 45203 tons of cocoa and mean annual rainfall of $1169.8 \mathrm{~mm}$, the reduction in the cocoa yield in this year can be attributed to shortage of rainfall which was actually below the minimum amount of rainfall required for the growth of cocoa crop. As noted by International Cocoa Organization (ICO 2010), cocoa required at least $1450 \mathrm{~mm}$ of rainfall to thrive very well. It is very obvious from this graph that the quantity of yield is a function of availability of adequate rainfall, though there was a lot of variation between the yield and rainfall whereby the rainfall was high but low yield was recorded which can be attributed to the distribution pattern of rainfall. The 2008 witnessed increase in rainfall with $1681.38 \mathrm{~mm}$ compare to 2005 with $1496.8 \mathrm{~mm}$ but more yield was recorded in 2005 than 2008, in this case emphases on the distribution of rainfall cannot be ignored i.e. when rainfall is high during the flowering period of cocoa it will reduce the yield because 
some of the flowers would have been removed by rainfall. However in comparing the yield and rainfall, distribution and period of rainfall are very important factors to consider. Generally, it can be deducted from this analysis that rainfall is a very important parameter that led to increase in the area cover by cocoa plantation as the change that took place in cocoa plantation class of the land cover of Ondo state. Therefore, there is a strong correlation or relationship between gradual increases in rainfall and increased in the area of land covered by cocoa plantation in the study area within the investigated time of this research.

\subsection{Regression Model}

Regression model was employed as an inferential statistical approach to measured how important rainfall as the most unstable climatic parameter determine the cocoa yield. In this regards, rainfall is independent variable while cocoa yield was set as the dependent variable.

The rainfall data from Ondo State agroclimatological station and cocoa yields from Ondo State ministry of agriculture and forest resources from year 2000 to 2014 was subjected to regression analysis in order to infer or drawn certain conclusion about how the rainfall flunctuation affected cocoa yields during the period of investigation. This is solved by applied the most widely measured of goodness fit equation line of $y=a+b x$ related to bivariate data express as: $\left(x_{1} y_{1}\right) \ldots \ldots \ldots \ldots \ldots . .\left(x_{n} y_{n}\right)$, this is the sum of the square deviation about the line expressed as: $\sum[y-(a+b x)]^{2}=\left[y_{1}-\left(a+b x_{1}\right)\right]+\left[y_{2}-\left(a+b x_{2}\right)\right]^{2} \ldots \ldots \ldots \ldots \ldots \ldots+\left[y_{n}-\left(a+b x_{n}\right)\right]^{n}$.

These can be expressed by an equation of the form:

$Y=b_{0}=b x_{1}=b_{2} \ldots . b x_{n}=\sum \equiv$

Where:

$$
\mathrm{y}=\text { dependent variable }
$$

$\mathrm{b}_{0}=$ constant term

$\mathrm{b}_{1,2}=$ regression coefficient

$\sum=$ error term that can enter the model

$$
r=\frac{\sum x y-\frac{\left(\sum x\right)\left(\sum y\right)}{n}}{\sqrt{\sum x-\frac{\left(\sum x\right)^{2}}{n}} * \sqrt{\sum y-\frac{\left(\sum y\right)^{2}}{n}}}
$$

The outcome of regression analysis reveals strong tied on how rainfall variation affect the cocoa yield as one of phenological factors that determine the cocoa yield. The explanation from analysis depict y-dependent variable which represent the cocoa yield in tons in Ondo state from year 2000 to year 2014 while the amount of rainfall measure in millimeter represent the indepent or explanatory variable depicted as' $x^{6}$. The result show very strong 
relationship between rainfall and cocoa yield with 0.97 correlation coefficient result. This implies that the more the amount of rainfall recorded and well distributed within the range of amount of rainfall required for the growth of cocoa, the more the cocoa yield and the vice versa all other factors remain constant. This establishe the fact that few millimiter of rainfall deviation above or below the range of the required amount of rainfall for the growth of this crop is heinous to yield of this plantation. Hence, addiquate attention should be given to rainfall consideration for better cocoa yield in Ondo State because this parameter is the most unstable natural factor for cocoa raising in this region because this plantation is purely rainfed agriculture.

\section{Conclusion}

Cocoa farming is a typical rainfed agricultural practice that required high amount of rainfall with at least seven months of distribution which is a condition beyond the control of man. The variation in the amount and distribution of rainfall in the tropic has been greatly caused by antropogenic activities mostly deforestation as the situation is in the tropical rainforest region of Ondo State. The consequence of these human activities in this region have great impact on the yield of cocoa as the largest cocoa producing state in Nigeria (National Bureau of Statistics, 2011). Rainfall is considered as the most unstable climatic parameter and of course one of the most difficult humanly enhanced natural factors responsible for the growth of cocoa (Boyer, 1982). The more efforts government can put to control human activities especially deforestation in this region to stablize the amount and distribution of rainfall, this will go a long way to improve cocoa yield as the highest contributor of agricultural crop to Gross Domestic Product of Nigeria over time. The outcome of this research will be very useful for the decision maker in Ondo State to control human activities that reduce the mean annual rainfall and its distribution and also to increase its investment on this plantation to increase cocoa yield and thereby increase the revenue derive from this crop.

\section{References}

Adebekun, O. (1978). Atlas of the Federal Republic of Nigeria. $1^{\text {st }}$ edition, under the chairmanship of National Atlas Committee, pp. 136.

Adefolalu, B.O. Stephen, and E.M. Tobi. (2014). Rainfall distribution and change detection across climatic zones in Nigeria. Weather and climate extreme journal of Science Direct, Vol. 5-6: pp. 1-6.

Adegeye, A. O. (2006). Introduction to forest entomology and pathology. Faculty of Agriculture and Forestry, University of Ibadan Nigeria.

Agboola, A. F. (2005). Socio-economic assessment of farmers' usage of indigenous and non-indigenous pest control technologies in cocoa agro-ecosystems of Ondo and Osun states of Nigeria. Department of Agricultural Extension and Rural Sociology, Obafemi Awolowo University, Ile-Ife, Nigeria.

Anim-Kwapong G.J, Frimpong E.B (2005). Vulnerability of Agriculture to climate change: impact of climate change. New Tafo Akim: cocoa research institute of Ghana. 
http://www.nlcap.net/fileadmin/NCAP/Countries/Ghana

/COCOA_DRA

FT_FINAL_REPORT.pdf.Accessed on 02/09/09.

Boyer, J.S. (1982). Plant productivity and environment. Science 218: 443-448.

Ekanade, O. (1990). An evaluation of soil productivity in inter-planted cocoa and Kola environmental systems in Southwestern Nigeria. International Journal of Environmental study, Gordon and Breach science publications, UK, Vol.35: pp.253-261.

Food and Agricultural Organization of United Nations Statistical Database (2012).

International Cocoa Organization (ICCO) (2003). ICCO quarterly bulleting of cocoa statistics. Accessed <http:// www.icco.org/statistics/production-and-grindings/production

Jagtap, S. (2007). Managing vulnerability to extreme weather and climate evens: Implications for agricultural and food security in Africa. Proceedings of the international conference on climate change and economic sustainability at Nnamdi Azikiwe University, Enugu, Nigeria. $12^{\text {th }}-14^{\text {th }}$ June, 2007.

Jones, P.G. and Thornton, P.K. (2002). Croppers to livestockers: Livelihood transition to 2010 in Africa due to climate change. Global environmental change, World Health Organization, Geneva, Switzerland.

Hokana, F. (1994). World cocoa bean production. Agricultural production, 10, 36-39.

Nwafor, J.C. (2007). Global climate change: The driver of of multiple causes of flood intensity in Sub-Saharan Africa. Paper presented at the international conference on climate change and economic sustainability at Nnamdi Azikiwe University, Enugu, Nigeria. 12 $14^{\text {th }}-14^{\text {th }}$ June, 2007.

Olajide, M.G. and S.O. Adeogun (2006). Assessment of cocoa growers' farm management practices in Ondo state Nigeria. Spanish journal of Agricultural research, Vol. 4(2): PP.173-179.

Oyedele, J.O. (2007). Enhancing the sustainability of cocoa growing in Nigeria. A paper presented at the cocoa roundtable on sustainable world cocoa economy, Accra, Ghana, 3-6 October.

United Nations Framework Convention on Climate Change (2007). Climate change impact, vulnerabilities and adaptation in developing countries. UNFCC Secretariat, Martin-Luther-King-Stratze 853175 Bonn, Germany. (Available and accessed on http://www.unfcccint 2007).

Ziervogel G., A. Nyong, B. Osman, C. Conde, S. Cortes, and T. Dowing (2006 ). Climate variability and change: implications for household food security. Assessments of Impacts and Adaptations to Climate Change (AIACC) Working Paper No. 20, January 2006. The AIACC Project Office, International START Secretariat, Washington DC, USA.

Zoellick, Robert B. A. (2009). Climate Smart Future. The Nation Newspapers. Vintage Press Limited, Lagos, Nigeria. Page 18

\section{Copyrights}

Copyright for this article is retained by the author(s), with first publication rights granted to the journal. This is an open-access article distributed under the terms and conditions of the Creative Commons Attribution license (http://creativecommons.org/licenses/by/4.0/). 